\title{
INTERNATIONAL TAX RELATIONS
}

\author{
HENRY S. BLOCH and CYRIL E. HEILEMANN $\dagger$
}

\section{Foreign Tax Policy and Economic Objectives}

THE foreign tax policy of a nation consists of its tax policy towards its nationals and organizations as far as their dealings abroad are concerned and towards foreign individuals and organizations as far as they become subject to its taxing powers. A nation's policy decisions with respect to these matters vary with the nature of its basic economic characteristics and also with its orientation in foreign economic policy.

It is inevitable that in a world of limited trade and scant international cooperation certain countries will feel coerced to take discriminatory and "protective" measures. Moreover, it must be understood that not all discriminatory or protective measures are essentially restrictive of international trade or investment. In some instances they may lead to an "extension of a partial free trade area." 1 Yet even if there were completely free trade and flow of investment, periods of transition and temporary disturbances might warrant special tax measures. The need for economic development and the lack of foreign exchange are causes which may induce a country to use a protectionist or discriminatory tax policy for the achievement of general economic aims.

There are a few specific areas in which taxation eo ipso can interfere with the normal development of international economic relations or where it can be used to correct a lack of balance. Taxes (apart from tariffs) can be used to discriminate against imported merchandise. ${ }^{2}$ -Use taxes, consumption taxes, excises of various types can function as trade barriers and have often been used in addition to or in lieu of tariffs. Taxes can be levied in such a way as to discriminate against articles earmarked for export. ${ }^{3}$

$\dagger$ H. S. Bloch is a member of the Division of Tax Research and C. E. Heilemann of the Office of the Tax Legislative Counsel in the United States Treasury Department. The views expressed by the authors are stated as their own, and no attempt is made to represent the position of the Treasury Department. Thanks for useful comments are due to Messrs. J. L. Mosak of the Office of Economic Stabilization and Earl Hicks of the Treasury Department.

1. Compare Bernstein, British Policy and a World Economy (Dec. 1945) 35 AM. Econ. Rev. 891 el seq., especially at 907. Dr. Bernstein's article shows the various effects of protection measures under different economic conditions which apply not only to the British Empire, but have general significance.

2. E.g., the United States internal revenue taxes on oleomargarine and filled cheese, INT. REv. CODE $\$ \S 2306,2356$ (1940).

3. Export duties have been widely used in varying forms. Some South American countries make extensive use of export duties. See Groves, Financing Government (1939) 444. Prior to World War II, Italy levied special export duties on materials which were considered either critical or strategic. This is evident from the list of the articles given 
Foreign capital can be discouraged by discriminatory levies "or by generally high taxes, or it can be encouraged by the prospect of generally low rates of taxation or by rates which are especially low for foreign capital. Domestic capitalists can be discouraged from investing abroad by special tax discrimination or they can be encouraged to do so through advantages offered especially to capital invested abroad. ${ }^{5}$

In all these cases, taxation is likely to be one of many factors determining either the movement of goods, capital and persons or the location of enterprises. ${ }^{6}$ Its marginal effect varies from case to case. In general, prohibitive and restrictive policies can better be enforced through administrative devices of a more direct nature than by tax policy. Tax incentives, however, can often be effectively added to generally favorable conditions, and while they are not likely to reverse trends in movements of capital or persons, they can contribute to such developments and sometimes foster an existing trend. In any case, tax differentials can have a considerable effect on profit margins. It is therefore possible that investors, either public or private, may seek and obtain tax advantages from capital-hungry countries. Bargaining for tax privileges can appear as an element of no mean importance in international economic negotiations between governments and between governments and private groups.

\section{Certatn ECononic Effects of Multiple TAXatron}

It is doubtful whether superimposition of taxes by several governmental authorities should be considered obnoxious per se, and it is even more doubtful whether it is always restrictive of international trade. $^{7}$

However, even a tax policy intended to be neutral may be an important element in international trade problems. Tax systems that contain no attempt to influence international trade may involve acci-

in The Italian Tax System as of January 1, 1935, Tax Systess of taE World (Tax Research Foundation, 7th ed. 1938) 313. See also various references to the use of export duties in Dalton, Princtiles of Public Finance (1936).

4. Italy had a special tas of $4.5 \%$ on the capital invested by foreign companies in Italian territory. See TAX SYSTEMS OF THE WORLD, op. cil. supra note 3, at 312. Other countries, including, for instance, Greece and Denmark, practiced similar diccriminations.

5. See China Trade Act, INT. Rev. Code $\$ \$ 261-265$ (1910); tax provisions for American business in United States possessions, INT. REv. CoDE $\$ \$ 251-252$ (1910); provisions for Western Hemisphere Corporations, INr. REv. CoDE § 109 (1940).

6. The "flight tax" or "emigration tax" applied by N.lzi Germany to emigrating refugees who exported their capital was an example of a combination of tax discrimination with a whole scheme of administrative devices. See 2 Hexggeler, Das Ixteriantionale SteUERREChT DES ERDBalls (Feb. 1940) 532-3(15).

7. Multiple taxation by governmental units in a federal system can be planned and systematized on the basis of principles governing allocation of revenues. Similar principles could conceivably work on an international basis. 
dental multiple taxation that can have considerable effect on international trade. Very high excise taxes which lead to an increase of the price of the taxed product may have an effect similar to that of customs duties. Moderate excises imposed by the exporting country to which are added similar taxes by countries of transit or importing countries may cumulatively have the same effect and ultimately result in a reduction of the total volume of trade.

It has been' stated that multiple taxation interferes with international investment (meaning direct entrepreneurial investment). If a capital exporting country levies taxes on its enterprises abroad, as does the United States, and these enterprises are taxed by foreign governments as well, one might argue that the entrepreneur is in a less favorable position abroad than the foreign entrepreneur who is taxed only by his native country. Supposing that this were true, could one make an economic case for the reduction of tax rates for foreign enterprises to a lower level than that which applies to domestic enterprises? From an economic point of view this amounts to a subsidy. A reduction for one group of taxpayers results in a relatively greater load for others. It discriminates in favor of national enterprises abroad as against national enterprises at home.

On general economic principles such discrimination is objectionable, ${ }^{8}$ but special causes may justify subsidies to domestic firms abroad on economic grounds just as there may be special reasons for subsidizing domestic investment. An example would be the subsidizing of an entrepreneur who mines a metal abroad which cannot be found at home and which is necessary as a raw material for domestic production. Even in this case it must be established that private entreprencurs can do the job better and cheaper than a government agency and that loans to a foreign country or company would not achieve better results. Moreover, if it is established that a subsidy is economically desirable, the form of the subsidy must be considered, and the tax subsidy must be compared with other types; income tax reductions are always of greater value to firms making large profits than to firms making small profits and of no value to firms suffering losses.

If one compares the position of the entrepreneur from a rich and highly developed country who operates in countries which are less developed with the position of the native entrepreneur, it appears that he has a number of advantages which may outweigh his disadvantages due to a higher tax burden. ${ }^{9} \mathrm{He}$ is often a monopolist or a quasimonopolist because, of concessions he is able to obtain, and sometimes

8. Non-economic arguments, especially those based on considerations of military strategy, can be made even if there is no economic justification.

9. He may not always have advantages over nationals of third countries which have lower tax rates. 
he has better access to raw material than native entrepreneurs. If the entrepreneur from the rich and highly developed country is a corporation which operates on a high level of vertical integration, it can cut its costs considerably below that of competitors. Technical experience and knowledge and the ownership of patents often give such entrepreneurs a head start in undeveloped regions.

Another advantage of the entrepreneur from a wealthy country is easier access to capital and, therefore, mass production. Even if he operates on a small scale he usually can obtain a much lower rate of interest in his country than the native of poor or undeveloped countries. The heavier interest burden for native entrepreneurs ${ }^{10}$ means that a higher proportion of the marginal yield of the investment of the native entrepreneur goes towards the payment of interest, and therefore the marginal increment of his investment must yield higher returns than that of the foreign investor domiciled in a rich country."1

A capital importing country may find that multiple tax burdens restrict capital investment. Such a country could justify low rates for foreign entrepreneurs or even special exemptions on general economic grounds. Foreign investment may be a conditio sine qua non for the development of the country. Even in this case, it must be recognized that direct entrepreneurial investment is not the only type of foreign investment. The Agreements of Bretton Woods, while according recognition to the desirability of international direct investment, give new importance to indirect investment through international loans. Such loans are fostered in particular for countries which cannot find capital at low interest on the open market and which are in need of funds for reconstruction or general economic development. This may appear to many governments as a more desirable and a more effective means of stimulating development than the use of tax privileges for foreign entrepreneurs.

Quite apart from strictly economic considerations, a case can be made against multiple taxation because of inequities which it may produce. The query is whether persons or firms in identical economic positions should be subject to unequal taxation merely because they have international contacts. Just as there is no equity in special privileges, it is contrary to principles of equity to impose on one group a heavier tax burden than on another in a similar position.

10. The native investor can sometimes borrow in the foreign country, but he usually has to pay higher rates than nationals of that country. In view of the capital ohortage in undeveloped countries, native entrepreneurs must almost always borrow if they engage in large-scale investments.

11. This is explained in an article by Yuan- $\mathrm{Li}$ Wu, International Capilal Irrestmert and the Decelopment of Poor Countries (1946) 56 EcoNossic Joursins 86. The author refero to interest rates paid by entrepreneurs in China as ranging from 12 to $20 \%$. 


\section{Solutions to International Tax Conflict}

In scanning the economic aspects, stress has been laid both on the use of taxation as an instrument of foreign policy and on the effects of multiple taxation. ${ }^{12}$ Examination of the legal background reveals that concepts of jurisdiction to tax underlie both of these problems.

Three widely accepted principles of jurisdiction may be generalized: (1) location of the item of taxation-situs of property or source of income; (2) location of the taxpayer-residence or domicile; and (3) nationality of the taxpayer. The claims which are made in support of each principle are familiar. The jurisdiction of situs or source finds the wealth within its power and affords it protection; the place of the taxpayer's residence or domicile has power over his person and confers its benefits upon him; the country of his nationality has the bond of political allegiance and affords him, in addition to other rights and privileges, its diplomatic services abroad.

Inasmuch as a nation need not limit itself to one principle of jurisdiction alone and may interpret the principles quite broadly, it can find legal basis for a wide use of the instrument of taxation. Moreover, it is not curbed under international law by the fact that multiple taxation or discrimination against aliens results from its actions. ${ }^{13}$

That nations may and do proceed in this manner produces multiple taxation, for one jurisdiction, looking primarily to the item of taxation under one concept, may levy its tax on a transaction, while another jurisdiction, using a concept which looks primarily at the taxpayer, may levy its tax on that taxpayer with respect to the same transaction. The possibilities for multiple taxation are further extended by the broad interpretations which may be given to the principles of jurisdiction. Thus two countries employing the concept of situs may each find, under different interpretations, that an item is situated within its sphere of taxability, and both may levy tax upon it. If a nation, through its internal laws or its treaty arrangements, exercises restraint, it does so for reasons of policy such as have been mentioned above and not because of established barriers of international law. ${ }^{14}$

12. Other economic aspects are outlined in connection with problems of evasion, avoidance and intergovernmental activity. See text discussion infra, at 1167, 1170.

13. 1 HydE, INTERNationas LAw (1945) 664, 666, 672, 674; but see letter from Sccretary of State to chargé at Bogota, April 28, 1888 quoted in 2 MOORE, INTERnational LaW DigEsT (1906) 59.

14. One barrier to taxation which is established sufficiently to have the force of law is that against taxation of another sovereign nation. Deperon, InTERnational Dounle Taxatron (1945) 6; French Republic v. Board of Supervisors, $200 \mathrm{Ky} .18,252$ S. W. 124 (1923). How far this principle may be carried is, nonetheless, far from well established. The income of another government may not be taxed, but does this apply to the income of a corporate instrumentality of a foreign government? I.T. 3789, 1946-6 INT. REV. BULL. 5. An ambassador, as the embodiment of his country, may be immune from excises of the 
Should a policy of restraint recommend itself, a nation may adopt one or more unilateral approaches. It may limit itself to one principle of jurisdiction for taxation as the Union of South Africa, for example, has done, selecting the principle of source of income as the sole criterion in levying its income tax. ${ }^{15}$ It may grant outright exemption to certain classes of income from foreign sources ${ }^{10}$ or to foreigners on certain classes of domestic income.17 Foreign taxes on income from foreign sources may be allowed, in whole or in part, as a deduction from (or credit against) domestic tax on that income. ${ }^{18}$

In view of difficulties in determining the correct amount of tax for which credit should be given, the credit system cannot be described as the simplest device for elimination of tax conflicts. Outright exemption is for simpler. Unlike outright exemption, however, the credit system assures that the taxpayer will not escape taxation completely through some quirk of circumstance. Indeed its effect is to leave the taxpayer with at least the burden of paying the amount levied by the country with the higher rate of taxation. Furthermore, the credit does not remove the foreign income from the tax base of the crediting country, an important consideration if the tax is levied at progressive rates. It will be observed that the credit also is free of the economic consequences described above, which attach to the exemption.

One of the interesting possibilities which appears in connection with the United States income tax credit is the willingness of this country to give the credit to resident aliens, provided that their countries of

receiving state. Should distinctions be drawn in the case of consular officers? M. T. 7, 1943 CoMr. Bull. 1151; HYDE, op. cit. supra note 13, at 1276, 1337 et seq.

15. Act No. 31 of $1941, \S 7$, as amended by Act No. 34 of 1942 and by Act No. 26 of 1943; BARNes, INCONE TAT HANDBODE (5th ed. 1944) 2.

16. See note 5 supra. Compare the exemptions conferred under the United Kingdom income tax on certain income from foreign sources not brought into the United Kingdom, Konstarr, The Law of Incose Tax (9th ed. 1943) 792 et seq.

17. The taxation of nonresident aliens, not engaged in trade or business in the United States, only on fixed or determinable, annual or periodical income from sources in the United States, thus foregoing taxation on capital gains or occasional sales is an instance in point. INT. REv. CODE $\S 211$ (19:0).

18. In the income tax field the United States led off with a credit for foreign taxes in $\$ \S 222$ and 238 of the Revenue Act of 1918, 40 STrir. 1073, 1080. Canada followed with a comparable device in 1919. In lieu of an expedient used in World War $I$, the British adopted, by $\S 27$ of the Finance Act of 1920 ( $10 \& 11$ GEo. V, c. 31), a partial credit for "Dominion" taxes equivalent, in the case of a like arrangement on the part of the Dominion, to the DDminion tax or one-half the United Kingdom tax, whichever is smaller, with additional relief where the Dominion does not afford relief from United Kingdom tzx. Ko:ssrass, op. cit. supra note 7, at 24 et seq. Application to other countries with which agreements are concluded, and technical changes in this relief were effected by Part V and the Seventh Schedule of the Finance Act of $1945(9 \& 10 \mathrm{GEO} .6$, c. 13) in connection with the British prosram for reciprocal agreements on avoidance of double taxation. This legislation is diceussed in THE ECONOMIST (1945) 721. 
origin reciprocate in the case of American citizens situated there. ${ }^{10}$ The idea is by no means unique, other countries having offered income tax exemptions on condition of reciprocity. ${ }^{20}$ This approach is especially valuable in that it makes possible the elimination of tax conflicts without the formalities and delays of treaty negotiations.

In treaty solutions of international tax conflicts, three principal avenues of approach are apparent. The first may be designated as "elimination of discrimination," the second as "relief from multiple taxation," and the third as "administrative cooperation." 21

The standard tax clauses of treaties of friendship and commerce are illustrative of the first. Typically, they are prohibitions against the imposition of higher taxes on the nationals of the one party to the treaty by the other party than the latter imposes on its own nationals. ${ }^{22}$ It should be noted that a typical clause of this nature has been interpreted by the United States Treasury Department as applicable only in the case of aliens resident within the United States, an interpretation which has been adhered to by the Department of State. ${ }^{23}$ But with the greater number of alien taxpayers within the jurisdiction, it follows that such clauses, even thus limited, will operate to prevent discrimination in the majority of cases. It will be observed at once that such clauses, while extensive in the number of cases covered, are limited in function. They secure no special privilege, nor are they designed to relieve the burdens of double taxation; they are negative, not positive in their nature. The only treaty approach which can be more limited in character is the "most favored nation clause" which

19. INT. REv. CODE $\S 131$ (a) (3) (1940); a similar policy is pursued in the case of the taxation of shipping profits, the United States having expressed itself as willing to exempt the profits of vessels registered in another nation if that country will reciprocate in the exemption of ships of American registry. INT. REv. CODE $\$ 212$ (b), 231 (d) (1940); cf. Article 30 of the Brazilian Decree-Law No. 5.844 with respect to air as well as maritime navigation.

20. Carroll, Developments in International Tax Law in 1937 (1938) 16 TAx MAGazine $75,77$.

21. A fourth, but minor type is the treaty provision seeking to protect nationals of one State from extraordinary or special levies of the other State. See the treaty between France and Spain of January 19, 1862, Art. V, par. 2: "Subjects of each of the two States are exempt in the other State from all military service, from all requisitions or war contributions, from advances or loans and all other extraordinary contributions which may be established as the result of exceptional circumstances, insofar as these contributions are not imposed on real property." Compare the treaty between France and Great Britain of February 28, 1882, Art. X.

22. "The nationals of either High Contracting Party within the territory of the other shall not be subjected to the payment of any internal charges or taxes other or higher than those that are exacted of and paid by its nationals." Art. I, Treaty of June 5, 1928 between the United States and Norway, 4 United States Treaties, 4528. Compare Art. IV of the same treaty with respect to death duties. Id. at 4529 ; HYDE, op. cil. supra note 13, at 664, n. 3.

23. 3 Hackworte, Digest (1942) 577. 
secures only non-discrimination as between aliens and leaves the countries free to favor their own nationals.

As noted before, in the absence of treaty provisions there is no generally recognized rule forbidding imposition of higher burdens upon aliens than upon the nationals of the taxing jurisdiction. ${ }^{24}$ Furthermore, in the absence of the ability of one state to enforce its tais claims within the limits of another state, ${ }^{25}$ any attempt to treat aliens and nationals alike in all respects may be found to be impracticable by reason of the fact that non-resident alien taxpayers will be beyond the power of the state. Only their incomes or property will be subject to control. A distinction between non-resident aliens and other taxpayers thus becomes convenient. Experience may dictate, as it has in the case of the United States, that a different system of taxing non-resident aliens from that employed in the case of citizens and residents is practicable or productive of revenue. ${ }^{23}$ Again, if the non-resident alien is to be taxed only on his income or property within the jurisdiction while the citizen or resident alien must bear progressive taxation on the totality of his income or property, equity will argue for allowing the non-resident alien smaller exemptions, credits or deductions in the computation of his tax. ${ }^{27}$

The most interesting of the treaties drawn up to prevent multiple taxation are treaties dealing with income and estate taxes. ${ }^{23}$ As with unilateral action, outright exemption and credit for foreign tax are the fundamental tools. ${ }^{29} \mathrm{~A}$ combination of both may be worked out so that with respect to some items of income or property, double taxation is eliminated by agreement that only one country shall tax, while with regard to other items relief may be sought through the credit. ${ }^{23}$ The comparisons made between outright exemption and credit in the discussion of unilateral solutions hold true as well for treaties. Thus the

24. See note 12 and text discussion supra, at 1162.

25. 3 BeAle, Conflict of Laws (1935) pars. 610.1, 610.2; Sacls, Nor-Enforement of Foreign Revenue Laws in International Law (1933) S1 U. OF PA. L. REv. 559; Deperon, op. cit. supra note 14 , at 6 .

26. INT. REv. CODE $\$ 211$ et seq.; Report of Ways and Means Committee on Revenue Bill of 1936, H. R. REP. No. 2475, 74th Cong., 2d Sess. (1930) 9 el seq.; Report of Sanste Finance Committee on Revenue Bill of 1936, SEx. Rer. No. 2156, 7tth Cong, 2d Ser. (1936) 21 et seq.

27. Compare Int. Rev. Code $\$ \S \$ 12, \$ 61$ (1940).

28. Mention should be made, however, of treaties to prevent double takation of sales, the multilateral convention on stamp laws signed at Geneva on June 7, 1930 and March 19, 1931, and the Geneva convention on the taxation of motor vehicles of March 30.1931.

29. Agreements to give reduced rates on particular types of income moving from one country to the other are not unknown. See Article VII of the United States-Swedin convention of 1939 with respect to a reduced rate on certain dividends and Article IX of the pending United States-United Kingdom convention for elimination of double taistion of income with respect to a reduced rate on real property rentals and mineral royalties.

30. As a matter of fact, a convention which employs the credit is likely to be a combi- 
principle of exemption recommends itself by reason of simplicity, but it has economic consequences and effects upon progressive taxation not attendant upon the credit.

Whether an exemption or a credit type treaty is written, decision must be made as to which country shall have priority, or, to state it from the other side, which country shall give up the right to tax or shall give credit for the other's tax. This means, in the case of the exemption type treaty, that either the jurisdiction of the source of income or the situs of property will be selected as the jurisdiction to levy the,tax, and the jurisdiction of residence, domicile or nationality will be the jurisdiction which it is agreed will give up the tax; or, contrariwise, the jurisdiction of source or situs will give up taxing and the other jurisdiction will be permitted to go on collecting the tax. Of course, income will be flowing both ways so that for some transactions one country will be the jurisdiction of source, whereas in other instances the second country will be the source, the same being true of situs. If the relation between the countries is such that one is predominantly a creditor, in the sense that its nationals are investors or entrepreneurs in the other, the balance of the flow of income will be from the debtor nation, and the greater part of property subject to taxation by both countries will be located there. ${ }^{31}$ It has been observed ${ }^{32}$ that as a result, creditor nations prefer the domicile type treaty and debtor nations the situs or source approach. On the other hand, a country in need of capital may be willing to forego taxing the return on that capital, at least for a limited period of time, and may, therefore, be willing to enter an exemption type treaty based on domicile for a number of years.

Just as credit and exemption may be mixed, so also may source and domicile. It is possible on some items of income or property to favor the jurisdiction of source while in the same treaty awarding the jurisdiction of domicile the right to tax other items. ${ }^{33}$

Theoretically, this same choice between source and domicile must be made in agreeing upon a credit treaty. As a matter of practice,

nation of methods. With respect to foreign business with no permanent establighment in the country, personal compensation of aliens temporarily present in the country, and like items, the exemption is generally preferred. Thus all existing effective United States double tax treaties use a combination of credit and exemption.

31. This situation may be reduced to the extent that investors and entrepreneurs from the creditor nation, leaving most of their income-producing property there, locate in the debtor country.

32. Ke Chin Wang, International Double Taxation of Income: Relief Through International Agreement, 1921-1945 (1945) 59 HARv. L. REv. 73, 114; DEPERON, op. cil. silpra note 14 , at 13.

33. The pending United States-United Kingdom income tax treaty is an instance in point, source being favored on business income, dividends, rents and mineral royalties, domicile being favored on interest, copyright royalties, and educators' salaries. 
recognition is given to the jurisdiction of source as the primary taxing jurisdiction, and the country of domicile gives the credit.

In items of income covered, the model income tax treaty recommended by the League of Nations experts at their conference in Mexico City is representative. This treaty includes provisions with respect to income from real property, industrial, commercial and agricultural enterprises conducted in both countries, ships and aircraft, compensation for personal services, government salaries and public pensions, income from movable capital, royalties from immovable property, patents, formulas, trademarks and copyrights, private pensions and annuities. ${ }^{34}$

The most intricate problem encountered in many of the income tax treaties is that of the business establishment with headquarters in one country but carrying on operations in both. If transactions between parent and branch or subsidiary are arranged as though their relations were those of independent establishments, it is comparatively easy to determine the income arising in each country. But to talie care of instances where the relations are not on an arm's length basis, the contracting countries may agree to allocate according to formulae which may, for example, be based on gross income, sales, or a relationship of receipts or assets of the branch to those of the parent.

The model estate tax convention deals with the location of real property and business property but leaves unsettled the situs of such items of personal property as stock, bonds, debts, corporeal moveables and bank deposits, often specified in treaties of this nature. An estate tax treaty outside the typical pattern is that concluded by the United States and Canada in 1945. Rather than specifying the situs of items of property, it provides that the jurisdiction levying a tax by reason of nationality or domicile must give a credit for the tax of the other country on property which, according to the latter's rules of law, is situated therein.

\section{Avomance and Evasion: The Problexs and its Solutions}

Frequently, conventions aimed at preventing double taxation are accompanied by provisions for cooperation in the administration of the revenue laws of the contracting states. Treaties have also been addressed to this subject alone. In glancing at them some profit is to be gained by applying the familiar distinctions between tax avoidance and tax evasion to the international tax picture.

With "tax avoidance" understood to mean legal means taken by a taxpayer to reduce or eliminate taxes, it becomes apparent that "tax:

34. For a more detailed analysis of the provision of the model convention on income tax recommended at the Mexico City conference see DepEror, op. cit. stspri note 14, at 22-27. 
avoidance" is readily possible in a "world of variegated tax systems. By foreswearing any connection with a country of high taxes and concentrating his interests and activities in countries of low taxation, the taxpayer can "avoid" taxes. Of course, a nation can make its taxes more difficult to avoid by widening the scope of its tax base, i.e., increasing the number of items upon which its taxes are levied. In other words, the taxpayer may avoid taxation by reducing the number of factors which connect him with a country; the country may make avoidance more difficult by increasing as a legal proposition the number of criteria which are sufficient to cause it to impose tax.

This does not hold true with the same force for "tax evasion," understood as illegal reduction or escape from taxation. Ease of evasion depends more on the nature of the taxation and the manner of its administration. It may still be true that the fewer contacts the taxpayer has with the taxing jurisdiction, the easier it will be to escape detection, but it does not necessarily follow that the fewer the bases for taxation the greater evasion will be. Indeed the reverse may be the case. While this qualification must be accepted, it is nonetheless possible that by giving up tax bases a country may create possibilities for the taxpayer to put on the appearance of falling outside the area of taxability.

Both avoidance and evasion result in tax leakages, thus reducing the total tax yield. Avoidance is as inequitable as evasion if the avenue of avoidance is only open to one category of taxpayers and not to another, although both are in the same economic position.

These elementary observations lead to some highly interesting conclusions when applied to tax conventions designed to prevent double taxation. Since the credit type of treaty does not reduce the bases upon which either party to it may levy taxes and results merely in the taxpayer paying an amount of taxes equal to the higher tax, it does not increase the opportunities for tax avoidance. It cannot prevent the taxpayer from minimizing his contacts with the higher taxing jurisdiction, but it does not permit him to retain those contacts and pay only the lower tax because the higher taxing jurisdiction has surrendered the right to tax. However, the tax convention which grants outright exemptions does just this. It may, therefore, be stated that an outright exemptions treaty increases the opportunities for tax avoidance. Where the opportunities lie at any particular time will depend on the comparative rates of the two parties to the treaty at that time.

Likewise, since the credit type treaty does not alter taxability, nor the manner in which the tax is administered, it does not promote evasion. On the other hand, the exemption type treaty creates possibilities for the taxpayer to give the appearance of falling within the exemption created and thus multiplies the possibilities of evasion as well as of avoidance.

To point out the superiority of the tax credit convention, so far as 
avoidance and evasion are concerned, does not lead to the conclusion that parties to such a treaty will have no interest in cooperating in the collection of their taxes through sharing of information or assistance of legal processes. Having adopted a course which does not encourage avoidance, there is little else they can do in this respect, for avoidance then depends on their internal laws and its reduction must be met by unilateral action. But evasion will persist unless there is cooperation. The outright exemption countries, while they have agreed to possibilities of avoidance, have an interest similar to that of credit countries in preventing evasion and a greater need because of the greater susceptibility to evasion which they may have created.

Capital movements are probably not considerably influenced by the desire to avoid or evade taxation. Specific transfers of capital and even of residence and citizenship have, however, been undertaken in order to make it possible to reduce the tax load in individual cases. ${ }^{35}$ International cooperation in this field has been handicapped by an attitude which has often identified the tax evader as a political rather than an ordinary criminal. ${ }^{36}$ During the period of the Nazi regime the fiscal laws of Germany have often been considered as immoral or contrary to the public order by other European nations, and international enforcement of fiscal claims was therefore an impossibility. ${ }^{37}$ If capital movements become freer and as the normal flows of trade are resumed, international concern with problems of evasion must become greater. As exchange controls are reduced and as other controls are loosened, it is quite possible that tax-motivated capital movements will become important. Many European countries are imposing capital levies, and if international collaboration against tax evaders is not strengthened, wealthy taxpayers could again resort to the use of capital transfers to avoid the impact of national legislation. ${ }^{33}$

The two principal lines of attack on evasion have already been mentioned. They are sharing of information on taxpayers and taxpayer activities and the use of legal processes to collect not only the taxes of the enforcing jurisdiction but also the taxes of the other jurisdiction.

Sharing information on taxpayers may be viewed as a mixed good, for there can be no assurance that a particular piece of information communicated to the other state will be used only for tax purposes. The problem is one of finding a balance between giving and obtaining

35. Hay v. Comm'r, 145 F. (2d) 1001 (C. C. A. 4th, 1914); see testimony of Colin F. Stam on the British double tax, Hearings before Commillec on Forign Relations on $H$. $R$. 2013, 79th Cong., 1st Sess. (1945) 72-73.

36. Jeze, Cours De Finances Publiques (France, 1936) 151.

37. Bloch, L'Assistance MFutzelle ent MFatière Fiscale, REvUE DE ScIENce ET DE LEGISLATION Financières (France, 1937) 159.

38. A discussion of capital movements and evasion is presented by PuTHER, L'Evasrost Fiscale et I'Assistance Adurnistrative entre Etats (1938) 122-172. 
all information which will be of assistance in enforcing taxes and not jeopardizing other interests which each nation may have. It is, therefore, customary to make reservations against disclosures of trade secrets, patents and processes and to reserve to each nation the right to withhold information in the interests of national security. A minor problem also arises concerning the extent of the duty which should be laid upon the authorities of one country to secure information for those of the other country. In most instances the sending of information regularly coming to the authorities of the transmitting country will be sufficient and may be provided for on an automatic basis. In individual instances more may be necessary, and it is, therefore, desirable to allow for request of specific information. Even in these cases the authorities cannot be expected to do more than is customary with respect to their own taxes, and information may be refused as unobtainable.

Cooperation in enforcement of taxes by legal processes involves not only a balance of policy considerations but also the traditional legal barrier to enforcement of the taxes of another jurisdiction. ${ }^{30}$ The solution which has met with the most favor is an agreement which does not allow the authorities of the taxing jurisdiction to come into the courts of the other country but provides that the authorities of the latter jurisdiction shall handle the claims of the other. Only those claims which have been finally determined in the taxing country will be pressed in the other's courts. This eliminates any possibility of litigation over taxability and hence any necessity for construing the tax laws of the other country, which may be a sufficient puzzle for its own courts. Measures of conservancy short of this may, however, be provided on request of the authorities of the taxing jurisdiction with respect to other tax claims. Just what this means has nowhere been exactly defined. It may be suspected that it is more in the nature of a sword which, hovering over the taxpayer's head, will induce him to settle his taxes rather than risk its descent. It may be argued that the contrariety of conservancy devices found in different countries would make enumeration burdensome. Yet because of the possibilities of litigation inherent in such uncertainty and because of the economic and social consequences attendant upon some "measures of conservancy," the subject deserves study and refinement of objectives, methods, results, and definitions.

\section{The Role of Intergovernmental Organizations IN THE Field OF TAXation}

Conflicts in the field of international tax relations have long been a matter of international concern. For over a century international agreements affecting taxation have been concluded between nations. ${ }^{40}$

39. See note 24 supra.

40. An agreement between France and Belgium covering double taxation and tax 
The modern tax convention which includes provisions against double taxation and fiscal evasion has been fostered by the expert worl of the Fiscal Committee of the League of Nations in the period between the two world wars. The Second World War interrupted this work, but the resurgence of international trade, reform of tax systems, and the introduction of extraordinary war profits taxes and capital levies have all given new impetus to intergovernmental negotiations in the field of taxation.

The Fiscal Committee was an outgrowth of a recommendation made by the Economic and Financial Organization of the League of Nations when it began to study the problem of double taxation and tax evasion in 1921. From 1923 to 1928 about four leading tax experts met at annual or biennial intervals under the auspices of the League. In 1929 this group of experts was given permanent status as the Fiscal Committee of the League, and it operated until MIarch 1946 when it was formally disbanded at a session in London. ${ }^{41}$

Most of the publications of the Committee deal with the prevention of international double taxation. However, the Committee also gave considerable attention to the prevention of fiscal evasion. The prevalent point of view was that agreements against fiscal evasion should be subordinated to those against double tavation. ${ }^{42}$ Moreover, it presented reports on principles of taxation ${ }^{43}$ and on fiscal policy and economic fluctuations. ${ }^{44}$ The most important practical contributions of the Fiscal Committee were model treaties for the prevention of double taxation and fiscal evasion. ${ }^{45}$

Most of the research work in the field of general fiscal policy was accomplished not by the Fiscal Committee but under the auspices of the Delegation on Economic Depressions and other subdivisions of the Economic, Financial and Transit Department of the League of Na-

evasion problems was concluded in 1843. On the historical development of such treatics sse Seligaran, La Double Imposition et la Cooperation Fiscale I:iterniatio:ala (1929)

45. For a text of the Franco-Belgian treaty see A. Piatier, op. cil. supra note 33, at 318-321.

41. See Report on the Wore of the Tenth Session of tue Fischl Consistee, League of Nations Doc. C. 37. M. 37. 1946 II. A.

42. This is brought out by Carroll, Prevention of Imteranational Dougle TaxaTION AND FiscaI Evasion (1939) 36-37.

43. League of Nations Doc. C.381.M1.229.1938. II.A (F/Fiscal 104); League of Nations Doc. C.181.M1110.1939 II.A (F/Fiscal 120).

44. The latter study was part of a Report of June 21, 1939, League of Nations Dos. C.181.M.110.1939 II.A (F/Fiscal 120) 6-16. The findings were based in part on a study of the tax sources of thirteen countries representative of different types of national economic structure during the period from 1928-35.

45. The latest of these model treaties are the Model BrLAteril Converitons for the Prevention of International Double Taxition amo Fiscal Evisioni, Ficeal Committee, Second Regional Tax Conference, Mexico, July 1943, League of Nations Dos. C.2.M.2.1945. II.A. 
tions. ${ }^{46}$ Between the study of fiscal policy in general and the limited study of double taxation is the area of problems which has been defined in this article as the "foreign tax policy of nations." 47 Though foreign tax policy was the major specialty of the Fiscal Committee, the field has also been developed by a number of private organizations, some of which deserve high credit. ${ }^{48}$

Private organizations representing taxpayers are, of course, primarily interested in reducing taxes. Such organizations or their representatives should not be forced into a position where they are made to appear in a role other than that of representatives of private, financial, commercial or industrial interests. As in all spheres of taxation, some of the problems arising in international tax relations may require solutions which hurt various private interests.

Foreign tax policy in its broader aspects must, therefore, be of interest to an international organization of governments such as the United Nations. In the long run, the governmental emphasis may become even stronger than it was in the League of Nations insofar as the treatment of governmental corporations may assume proportions as important as that of private corporations.

The Fiscal Committee of the League of Nations did useful work, particularly through its model treaties which, although not universally acceptable, have served to formalize significant findings in the field of international double taxation and tax evasion. The scope of the Committee's work can be considerably enlarged under a Fiscal Commission such as is being planned within the framework of the Economic and Social Council of the United Nations. ${ }^{49}$

As stated in the report of the Preparatory Commission, ${ }^{10}$ such a commission can study international tax problems in general, arrange for exchange of information among states on the techniques of government finance and on their social and economic effects, and analyze fiscal techniques used to assist the prevention of inflation or depres-

46. Examples are to be found in the series of League of Nations publications classified under II Economic and Financial Matters of Interest in Fiscal Policy. The most important recent publication is Economic Stability in the Postwar World (1945).

47. Ibid.

48. At least one author, the former Secretary of the Fiscal Committee, puts the work of the International Chamber of Commerce on the same level as that of the Fiscal Committee of the League of Nations. This is evident from the following sentence: "The chance is now offered of clinching the pioneer work of the International Chamber of Commerce and of the Fiscal Committee of the League of Nations." DePERoN, op. cit. supra note 14, at 5. It must also be noted that the International Chamber of Commerce was often offcially represented at sessions of the Fiscal Committee through one of its representatives who was a corresponding member of the Committee.

49. See Report of tee Preparatory Commission of the United Nations (Dec. 23, 1945) 38, 39, recommending the establishment of a Fiscal Commission of the Economic and Social Council.

50. Ibid. 
sions. Moreover, it can take over such functions of the Fiscal Committee of the League of Nations as it may decide to assume. ${ }^{51}$

This implies that the work of the Commission should reach beyond the scope of foreign tax policy per se into the questions of the international repercussions of internal fiscal policies, which would open the possibilities of linking monetary and fiscal studies within one commission or committee. Indeed, if full employment, stable exchange rates and free flow of trade are matters of international concern in general, then fiscal policies, too, must be a matter for international investigation. In one sense, the Fiscal Committee of the League of Nations was not really international, as the governments of the United States, U.S.S.R. and China, to name only major nations, were without official representation. The obvious tendencies of the United Nations' policy and of the reports of the Preparatory Commission point toward a broadening both of the geographical and of the functional scale of operation of the proposed Fiscal Commission.

51. Ibid. 